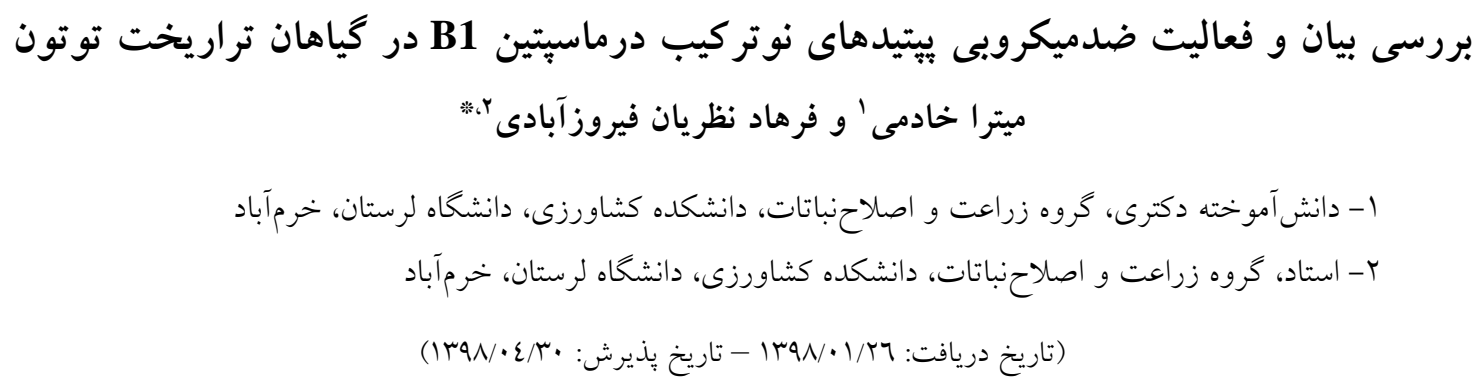

اخيراً، روش هاى جديد بهنزادى مولكولى و مهندسىزنتيك براى غلبه بر محدويتهاى بهنزادى سنتى در ايجاد كياهان مقاوم به

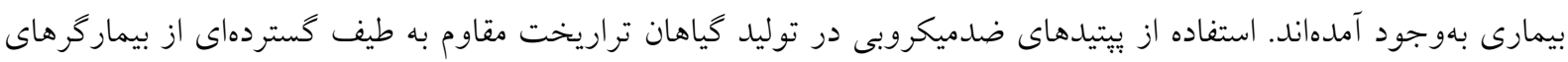

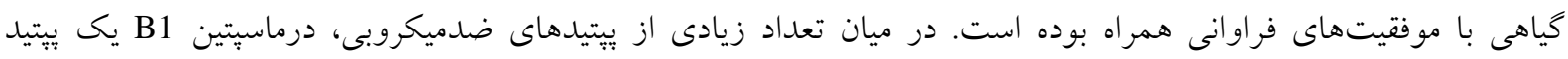

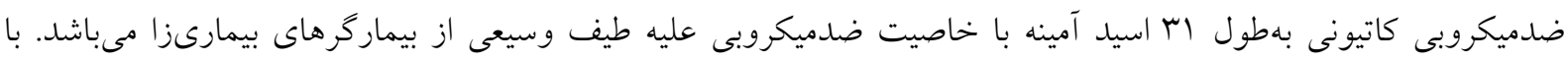

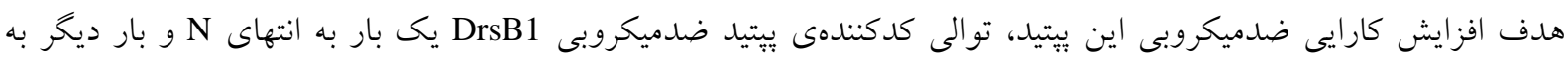

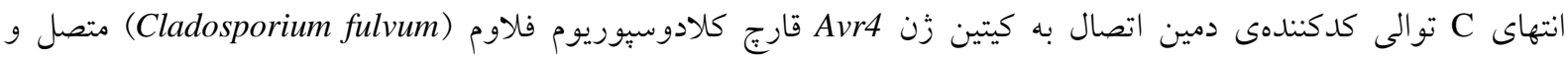

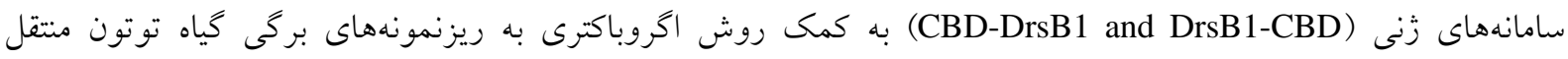

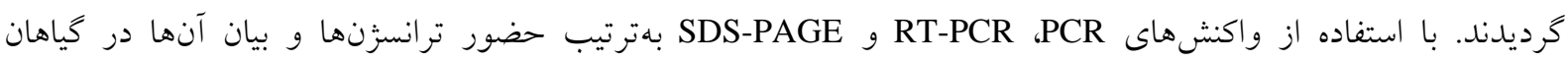

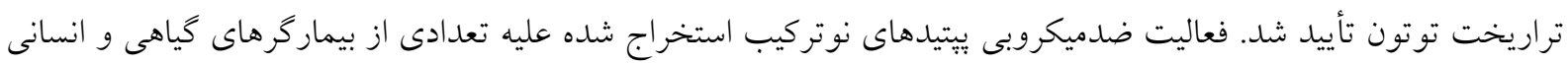

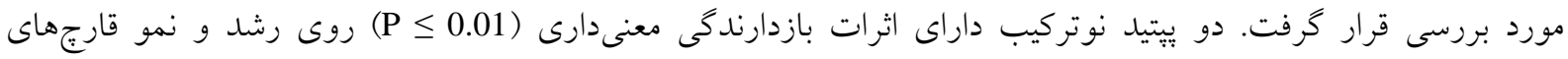

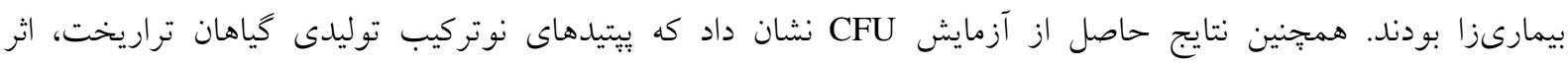

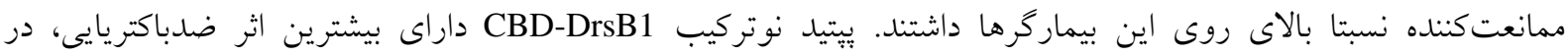

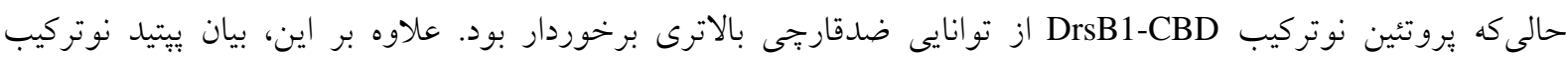

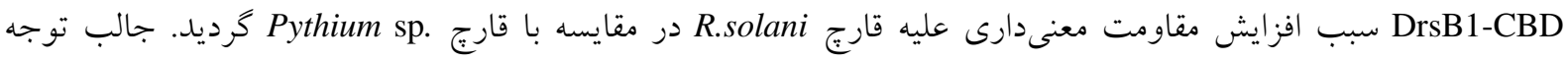

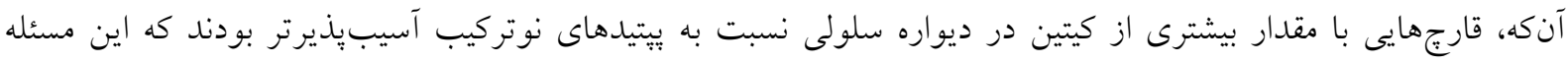

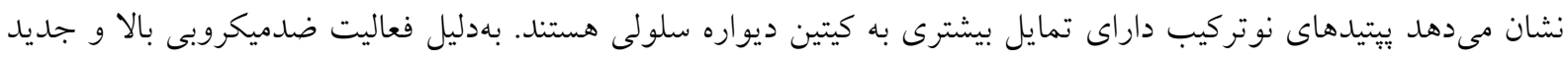

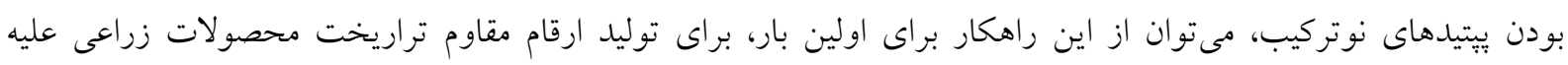
بيمار گرها استفاده نمود.

وازگًان كليدى: بيان زن، بيماركرها، يتيد ضدميكروبى، دمين اتصال به كيتين، مهندسىزنتيك 
توسط غدا يوستى برخى از خانوادهاى قورباغه

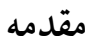
توليد و ترشح مىشوند، داراى (Phyllomedusa bicolor)

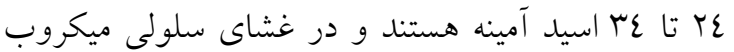
هدف حالت م-هليكسى بهخود مى گيرند و از اينرو سبب ايجاد نايايدارى در غشا مىشوند. تحقيقات نشان مىدهند كه هر خه تراكم مولكولى يبتيد

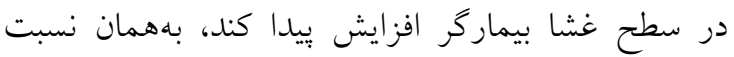
Flavia ( ميزان مرگ و مير بيمارگرها افزايش مى ميابد Cancado Viana et al., 2013; Li et al., 2011 در صورتى كه بتوان ميزان تمايل يّيتيدها را براى نزديك

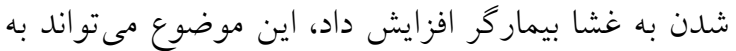

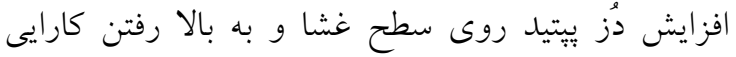
ضدميكروبى آنها كمك كند. ديواره سلولى قارج نقش مهمى در عملكرد ديناميكى و اثر

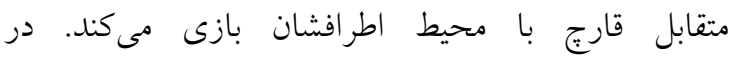
ياتوزنهاى قاريى، ديواره سلولى اولين ساختارى است

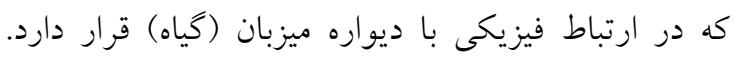

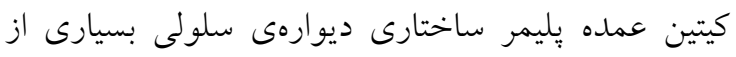

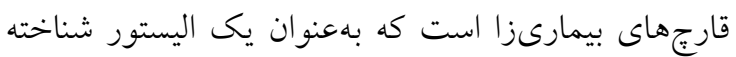

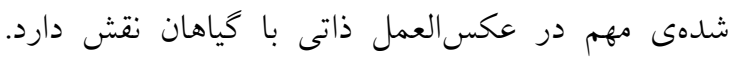

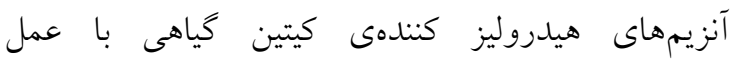
هيدروليتيكى خود روى ديون ديوارهى كيتينى سلولهاى

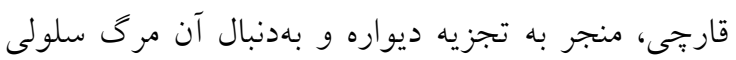

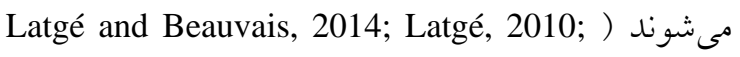
Thomma et al., 2011 راهكارهاى مختلفى از جمله تغيير در تركيبات ديواره سلولى، تغيير در زنجيره كربوهيدارت و ترشح افكتورها براى حفاظت از ديوارمى سلول خود به بكار مى خيرند .(Fujikawa et al., 2012; Latgé and Beauvais, 2014) براى مثال؛ در بيمارى كيك بركى كه توسط قارج

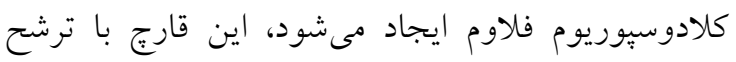
افكتورهاى Avr4 در زمان آلودكى باعث حفاظت ديواره سلولى در برابر آنزيمهاى هيدروليتيكى كياه مى دشود.

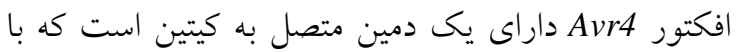
اتصال به كيتين موجود در ديواره سلولى قارج باعث

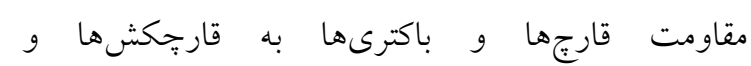

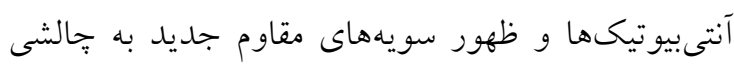

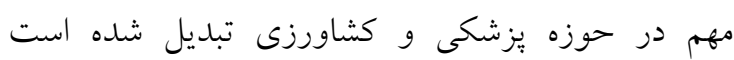
(Hunter et al., 1995; Vidaver, 2002) مرسوم و سنتى بهنزادى براى ايجاد واريتهاى زراعى

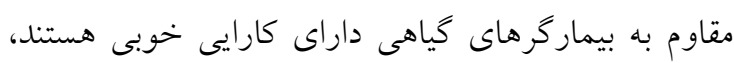

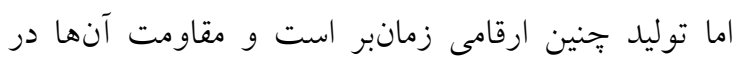
مدت كوتاهى در مقابله با طيف وسيعى از بيماركرها

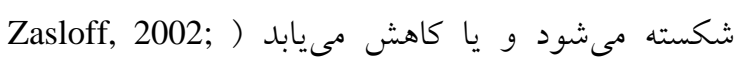
Nazarian-Firouzabadi, 2014; Hajiahmadi et al., 2017). ويزگ كى هاى منحصربهفرد يتيدهاى ضدميكروبى :AMPs) باعث شده تا اين (Antimicrobial peptides: AMPs)

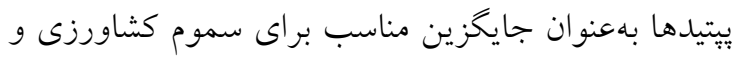

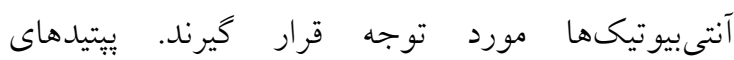
ضدميكروبى توسط طيف وسيعى از جانداران بيان مىشوند و بهعنوان يك سيستم دفاعى مورد استفاده قرار

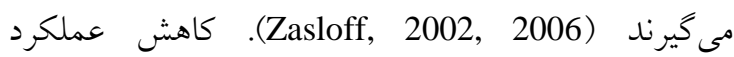
محصولات از لحاظ كيفيت و كميت ناشى از بيماركرهاى

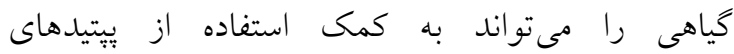
ضدميكروبى بر طرف نمود (Holaskova et al., 2015).

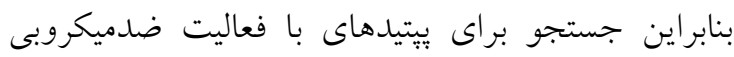

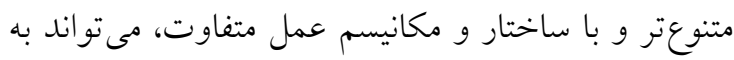
مقاومت كياهان بهطيف وسيعى از بيماركرها كمكى كند.

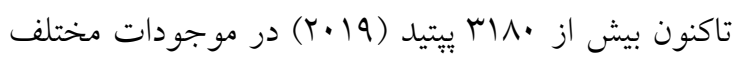

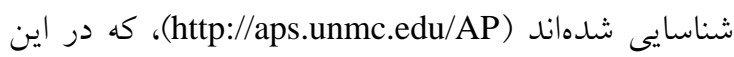

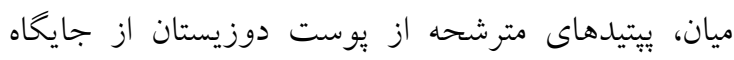

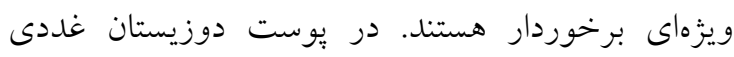

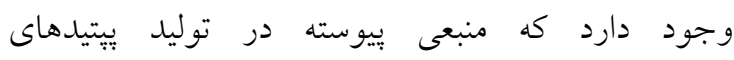

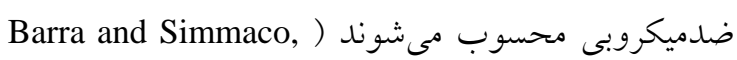
(1995; Conlon et al., 2004 قورباغهها، محل مناسبى براى رشد قارجها و باكترىها

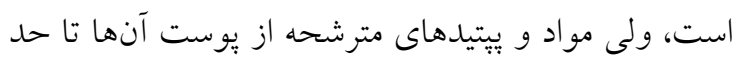

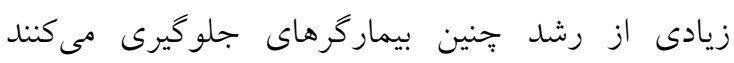
(Barra and Simmaco, 1995; Conlon et al., 2004) يتيدهاى كاتيونيك خانوادهى درماسيتين (DrsB1) B1) كه 
هم كشتى به مدت r تأ r روز در شرايط تاريكى در دماى

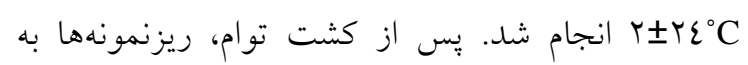

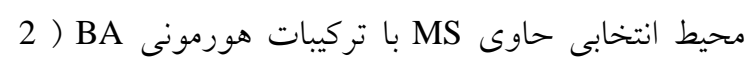

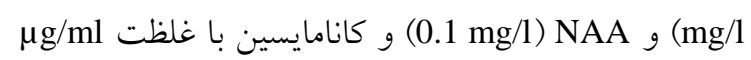

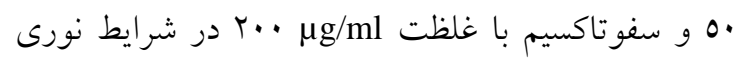

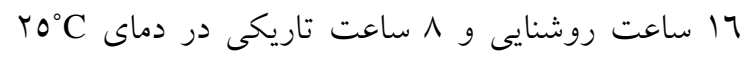

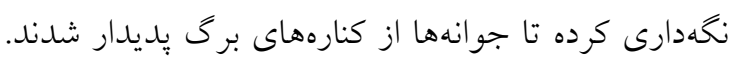

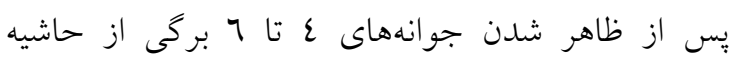

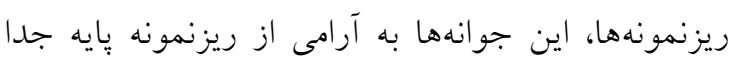

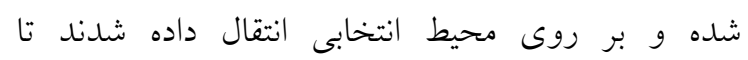

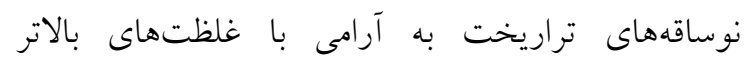

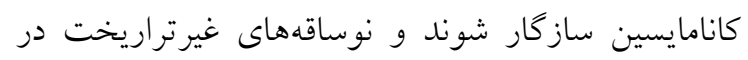

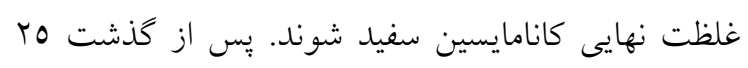

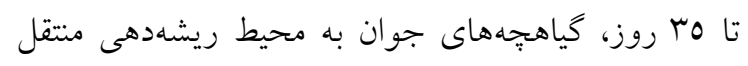

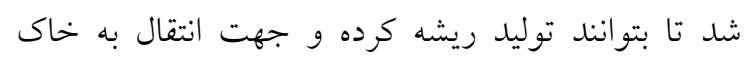

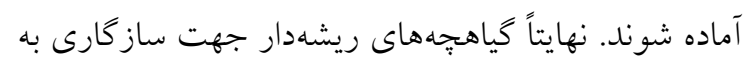

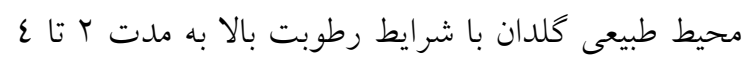
هفته انتقال يافتند.

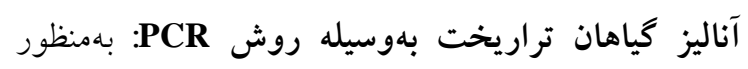

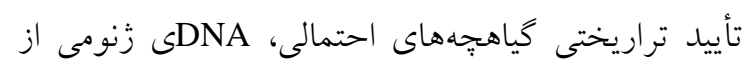
كياهجهها به روش CTAB استخراج شد. تعيين كميت و

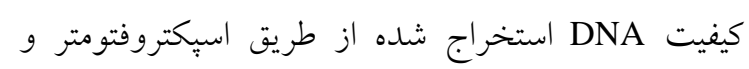

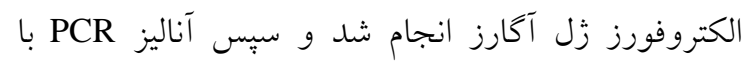

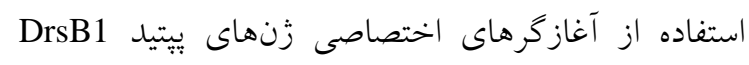
و DrsB1 F: GCTAAGGCTATGTGGAAGGATG) DrsB1 R: ATTGAGAAATAGTATCAGCAACA

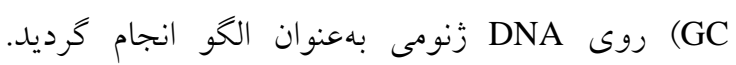

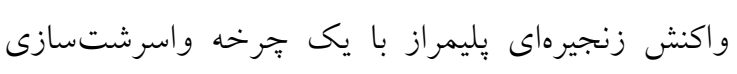

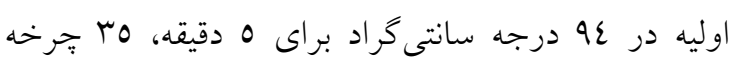

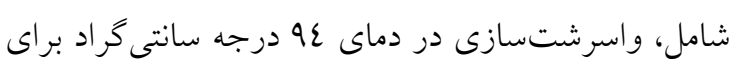

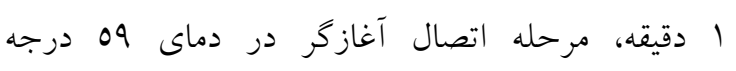

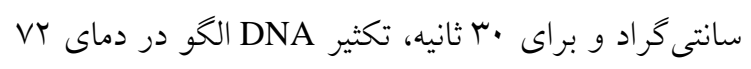

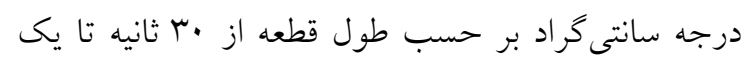

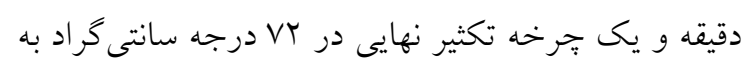
مدت 0 دقيقه صورت گرفت .
كاهش دسترسى آنزىهاى هيدروليتيكى ميزبان به كيتين

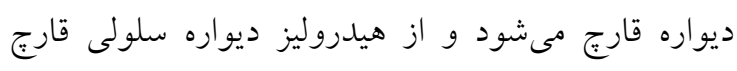
جلو كيرى مى كند (Van den Burg et al., 2006).

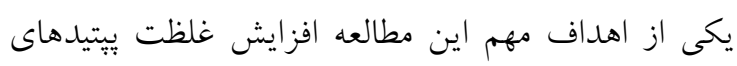

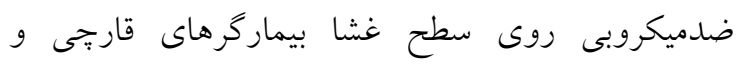

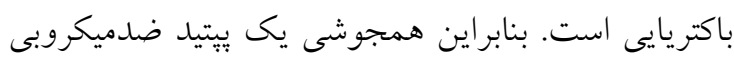

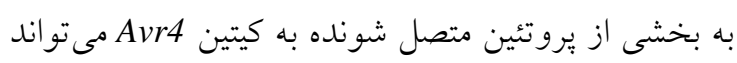

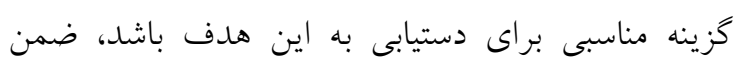

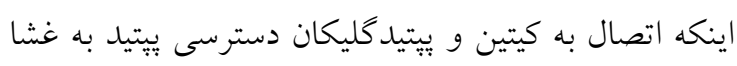

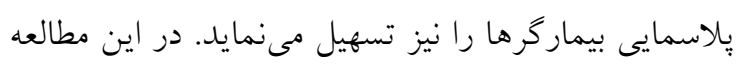

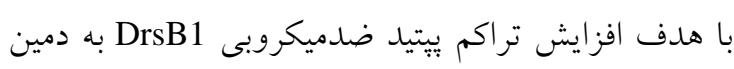

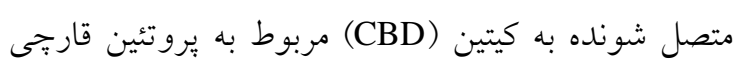

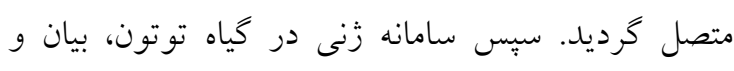

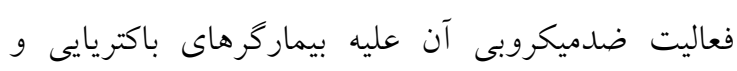

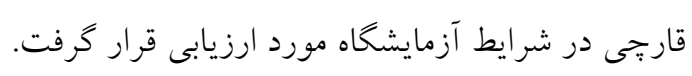

\section{مواد و روشها}

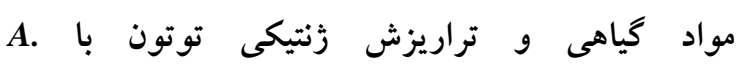
Xanthi به مدت • إدقيقه بذ بذون

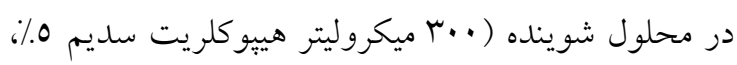

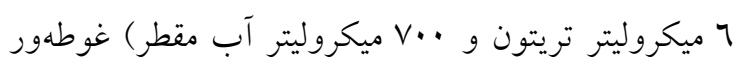

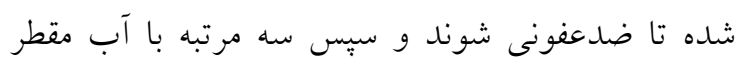

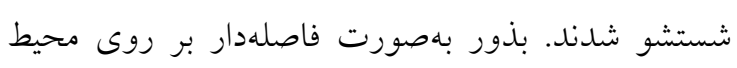

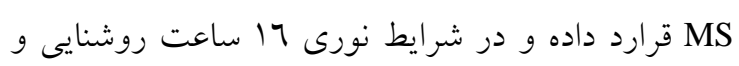

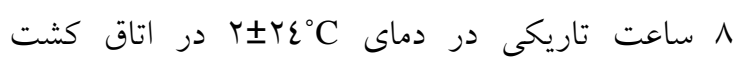

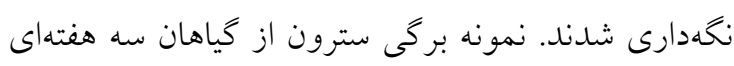

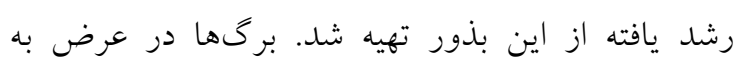

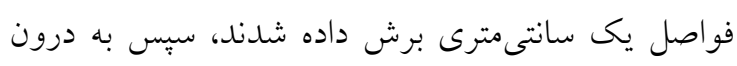

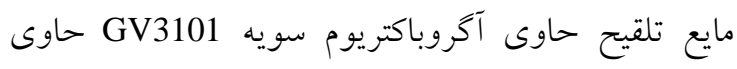
سازهاى طراحى شده كه قبلا توسط خادمى و همكاران

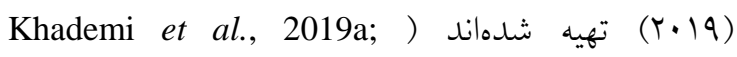
(Khademi et al., 2019b

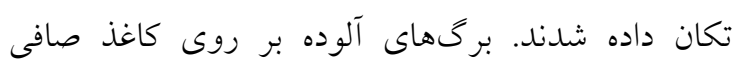

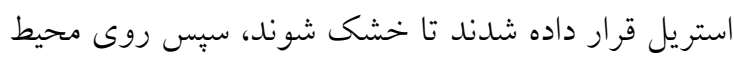

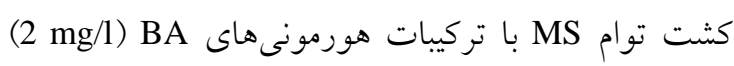
(0.1 mg/l) NAA, و بدون آنتىبيوتيك قرار داده شدنيات 
و PTCC 1330) Escherichia coli) كشت شب مانده تهيه شد. از كشت شب مانده كشت جديدى تهيه و وقتى

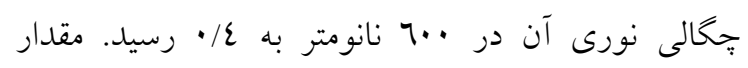

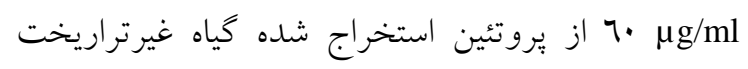

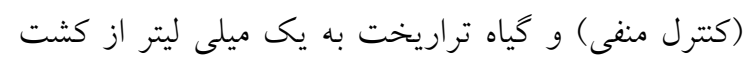

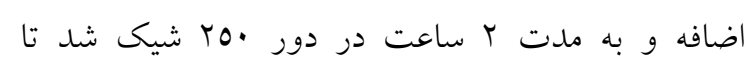

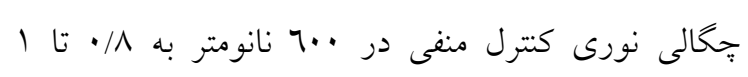

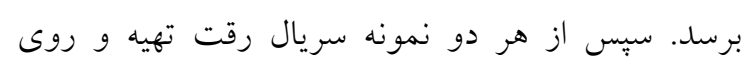

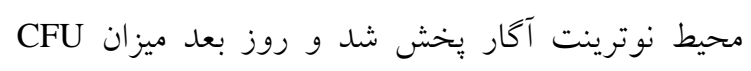

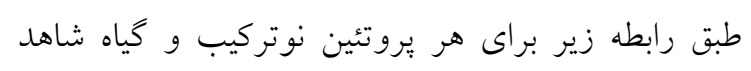
محاسبه و مقايسه شد. زئ زير براب

$(\%) \mathrm{In}=\frac{\mathrm{CFU} / \mathrm{ml}(\mathrm{Ut})-\mathrm{CFU} / \mathrm{ml}(\mathrm{T})}{\mathrm{CFU} / \mathrm{ml}(\mathrm{Ut})} \times 100$

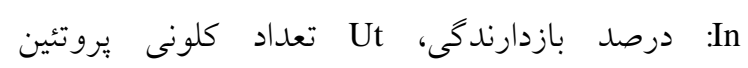
غيرتراريخت و T تعداد كلونى بروتئين نوتركيب (تيمار)

حداقل غلظت مهاركنندكى رشد (MIC) با استفاده از روش رقتسازى در لوله تعيين گرديد. تهيه سريال رقت

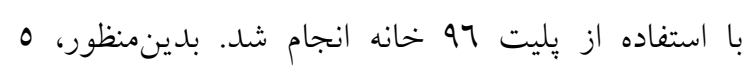

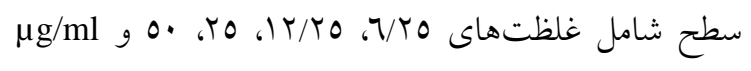

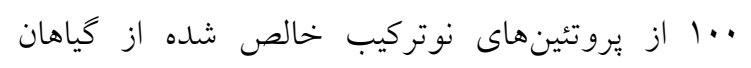

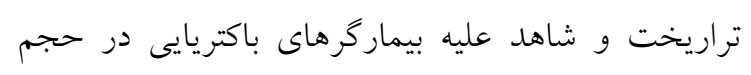

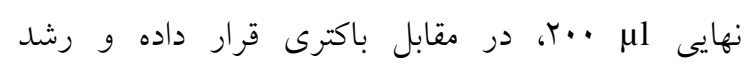

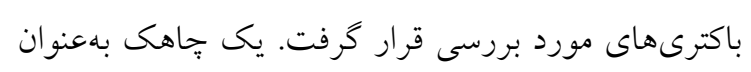

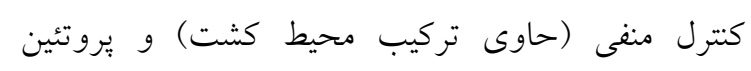

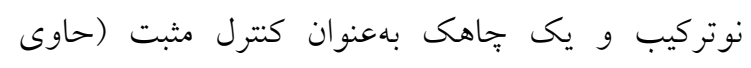

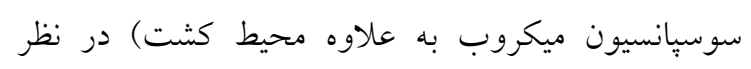

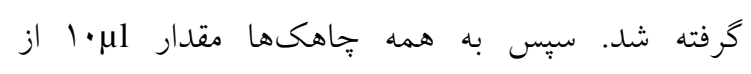

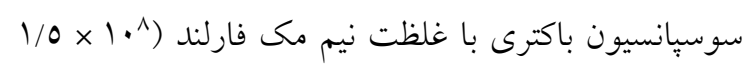

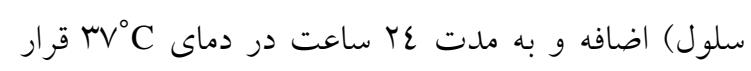

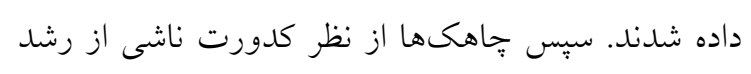
باكترى تلقيح شده بررسى كرديدند. با مشاهده ايجاد

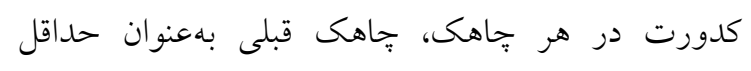

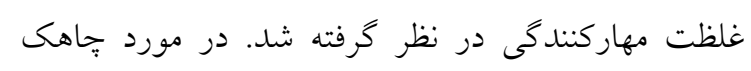
كنترل مثبت، كدورت نشاندهنده رشد كافى باكترى

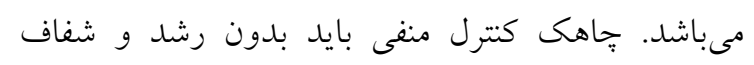

استخراج RNA و سنتز CDNA: بهمنظور تأييد بيان سامانهاى نوتركيب، استخراج RNA مطابق روش ليتيم

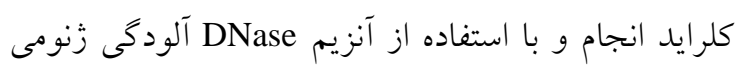

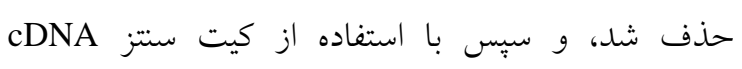

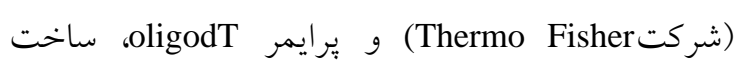
صورت كرفت. واكنش CDNA كاى سنتز شده، توسط آغازگرهاى اختصاصى واكى كترل داخلى اخلى elf- $\alpha$ R: , F:TGAACCATCCAGGACAGATTG

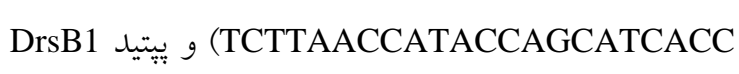

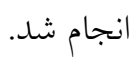
استخراج بروتئين: در ابتدا ا خرم بافت برى و ريشههاى

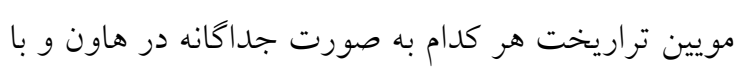

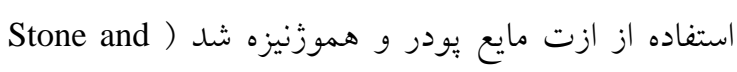

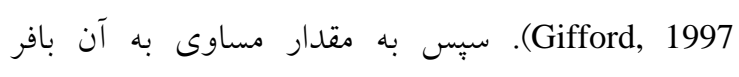

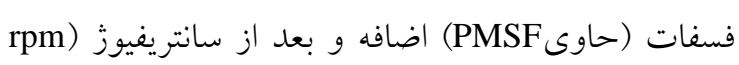

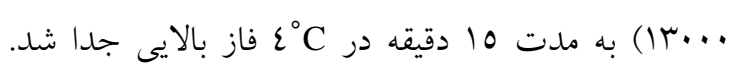
مايع رويى حاصل از سانتريفيوز كه حاوى يروتئينهاى

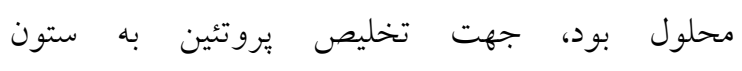
كروماتوكرافى حاوى رزين نيكل (PrepEase Ni-IDA) منتقل شد. ستون بهترتيب با محلول شستشو حاوى 5mM NaH2 $\mathrm{O}_{4}-300 m$ M NaCl جداسازى يروتئين نوتركيب از ستون، محلول شستشو

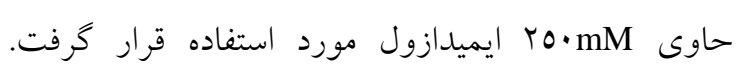

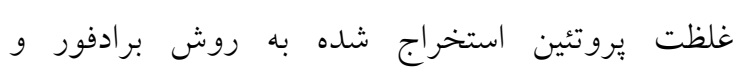

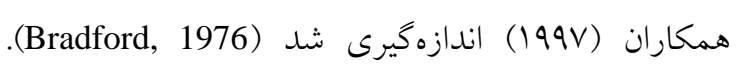

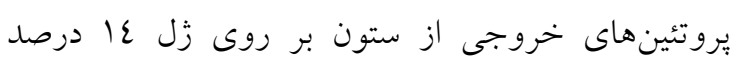

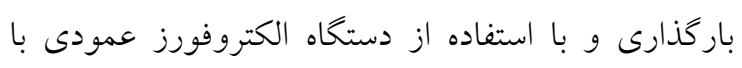

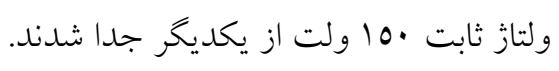

بررسى فعاليت ضدميكروبى بروتئينهاى نوتركيب عليه

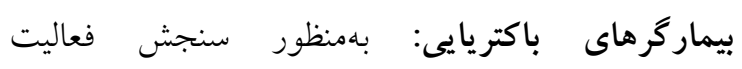

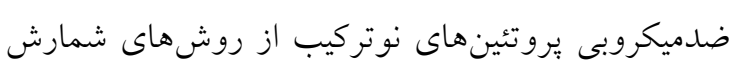

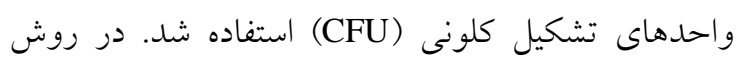

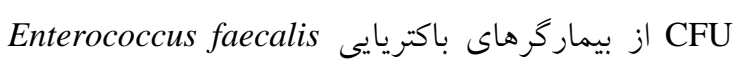
(KX185054) Enterococccus faecium ،(PTCC1393) 
بين تيمارها از روش آزمون جند دامنهاى دانكن در سطوح معنى دار مربوط براى مقايسه ميانخين استفاده شد.

نتايج و بحث

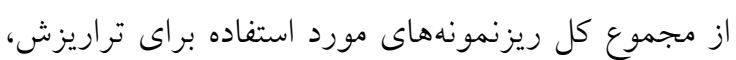

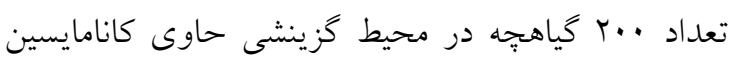

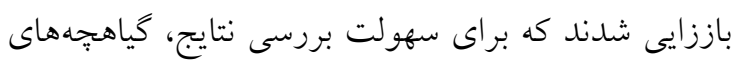

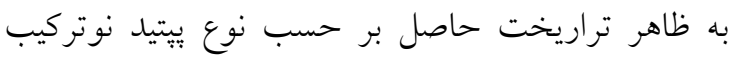

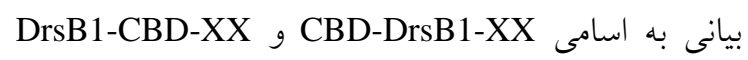
نام كذارى شدند كه XX نماينده شماره لاين تراريخت

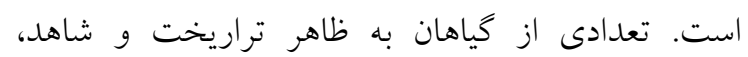
DNA

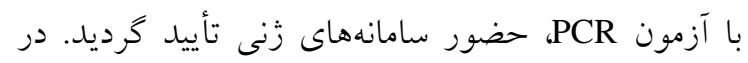

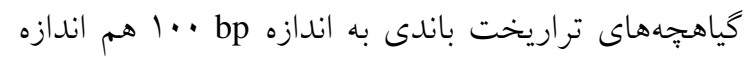

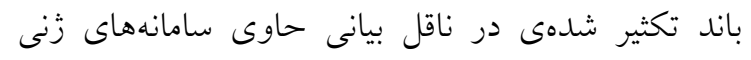

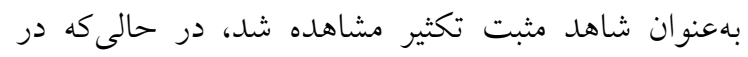

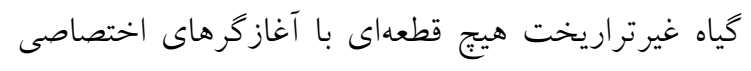

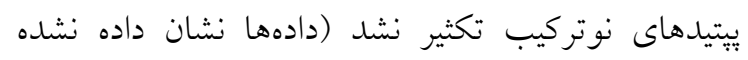
است). بيان هر دو ييتيد نوتركيب اين مطالعه در كياهان

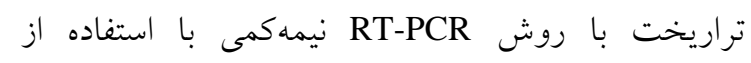

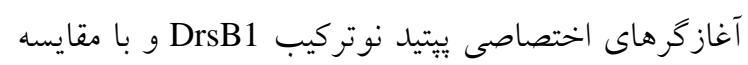

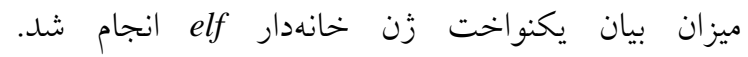

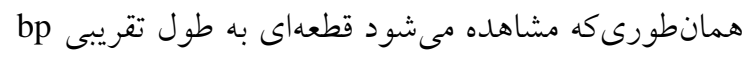

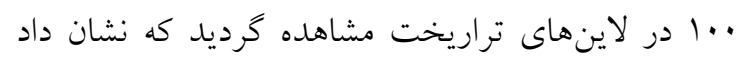
زنهاى مورد نظر بهخوبى در لاينهاى ترائ تراريخت نسخهبردارى مىشوند. همجنين با توجه به يكسانى باند روند

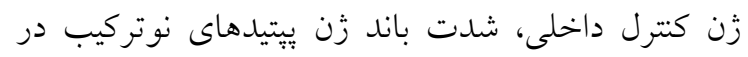

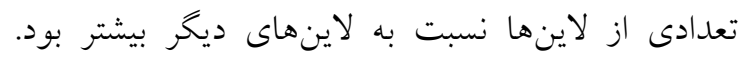

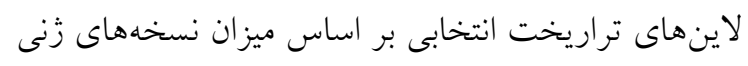

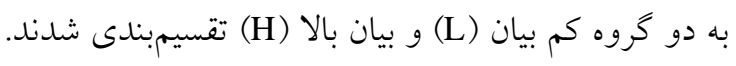

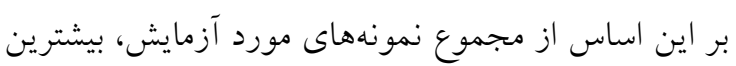

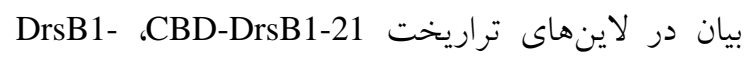
CBD-43 و CBrsB1-CBD-30 مشاهده شد (شكل A (1). همجنين بهمنظور بررسى و اطمينان از بيان و توليد

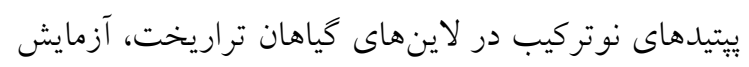

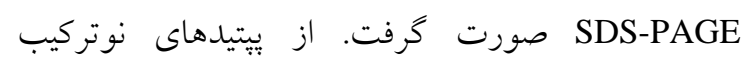

باشد (Vlietinck, 1991). براى هر باكترى اين آزمايش بهصورت جداگانه در سه تكرار طراحى و اجرا شد. بررسى فعاليت ضدميكروبى بروتئينهاى نوتركيب بر

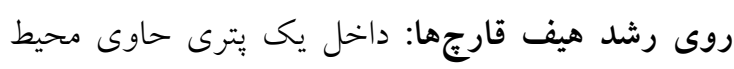

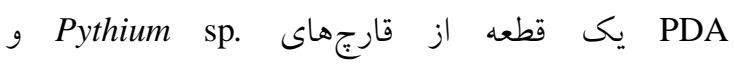
Rhizoctonia solani

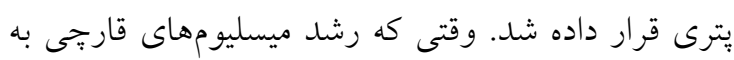

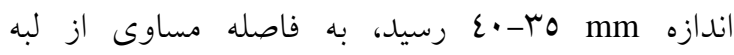

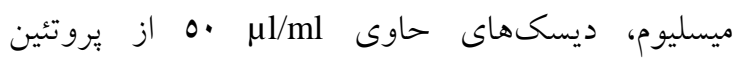
نوتركيب و شاهد در تماس با قارج قرار داده شدند و بعد ديدان

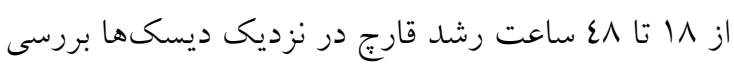

حداقل غلظت مهاركنندگى رشد (MIC) با استفاده از روش رقتسازى ميكرودايلوشن تعيين شد. در اين

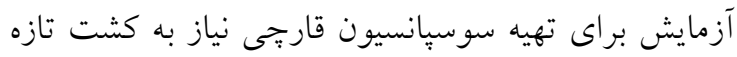

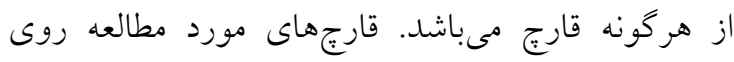

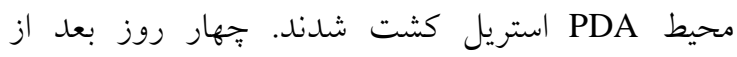

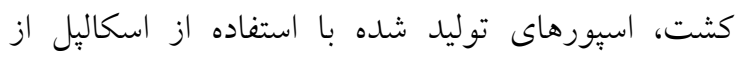

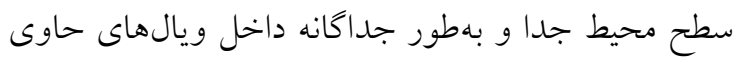

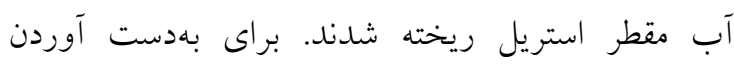

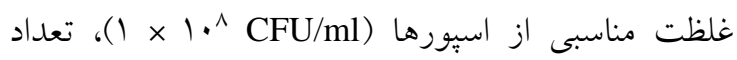

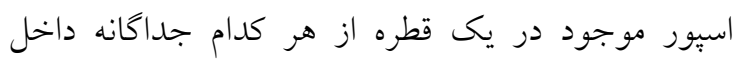

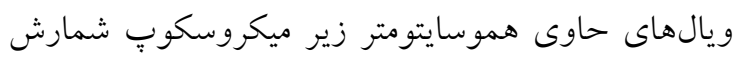

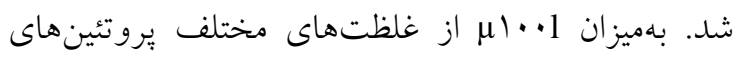

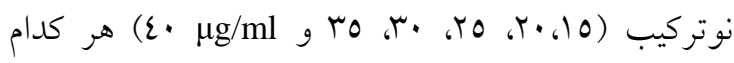
بهصورت جداكانه داخل ويال حاوى اسبور با حجم نهايى

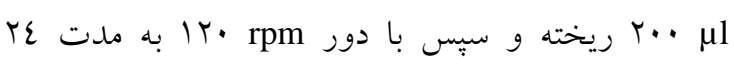

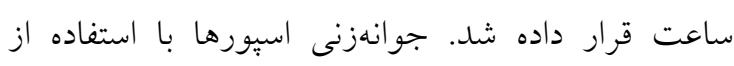
ميكروسكوب نورى و ميزان كدورت ناشى از راند رشد قارجهاى تلقيح شده بررسى گرديد.

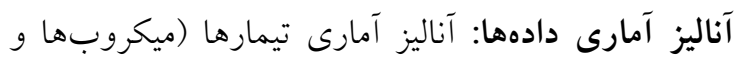

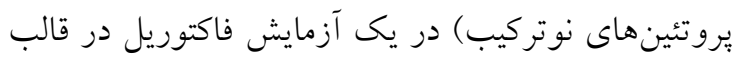
طرح كاملا تصادفى در r تكرار با استفاده از نرم افزار MSTATC انجام شد. در صورت وجود اختلاف معنى دار 


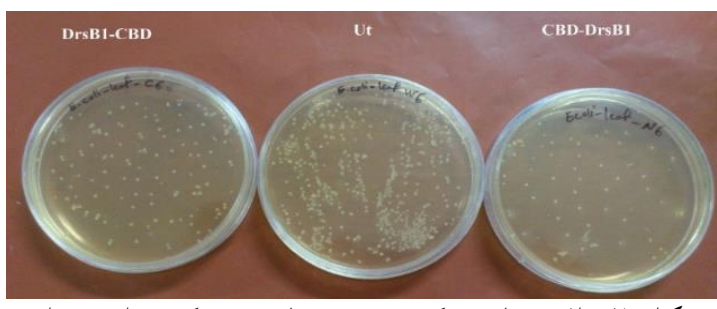

شكل r - اثر ممانعت كننده يِيتيدهاى نوتركيب استخراج شد نده در محيط

Figure 2. In vitro inhibitory effect of recombinant peptides extracted from transgenic lines

همجنين يروتئين كل از كياه غيرتراريخت بهعنوان شاهد

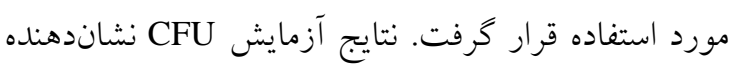

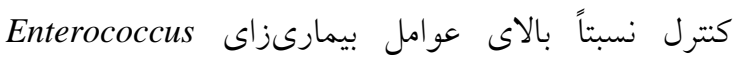

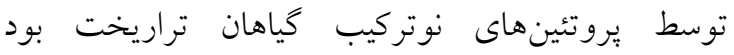
(جدول (). هم:جنين از نظر ميزان فعاليت بازدارندكى عليه

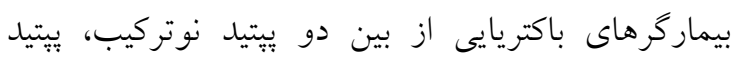

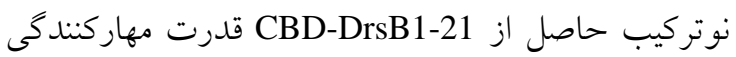

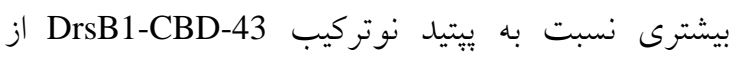

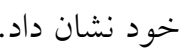

نتايج حاصل از حداقل غلظت مهاركنند نقى (MIC) فعاليت ضدميكروبى يبتيدهاى نوتركيب عليه بيماركرهاى

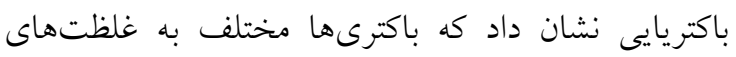

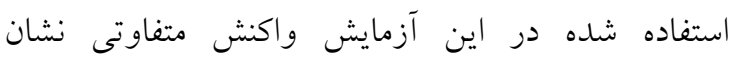
مىدهند. بهطور كلى، براى كنترل رشد باكترى E.coli

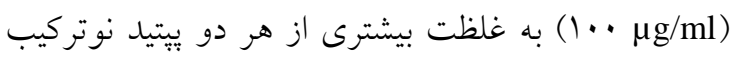

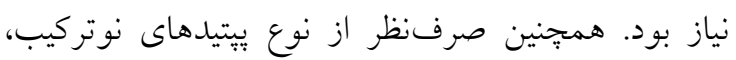

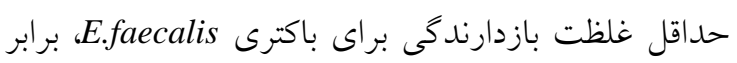

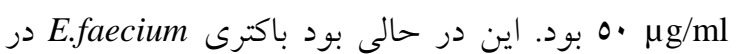

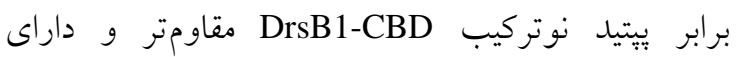

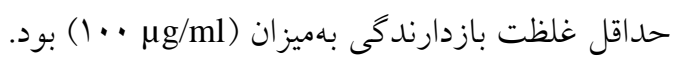
آزمايش فعاليت ضدقارجى يِّيدهاى نوتركيب استخراج

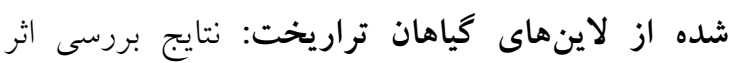
بازدارندكى بروتئين هاى نوتركيب استخر اج شده از كياهان

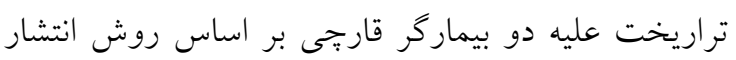

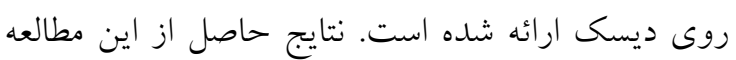

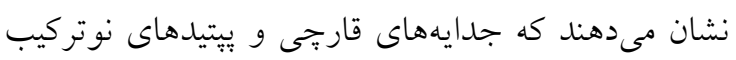

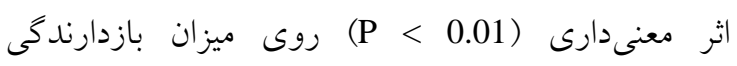

$$
\text { بيماركرها داشتند (جدول ب (Y). }
$$

خالصسازى شده با استفاده از ستونهاى كروماتوگرافى حاوى رزين نيكل براى خالصسازى دو ييتيد نوتركيب

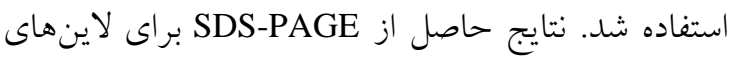
تراريخت بهخوبى نشان داد كه در لاينهاى كياهان تراريخت يِيتيدهاى نوتركيب توليد مىشوند. همانطورى كه مشاهده مىشود، يك باند با اندازمى مورد انتظار

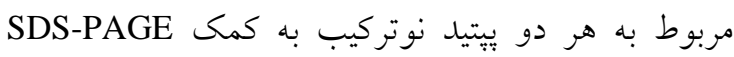
ديده مى شود. هيج باندى متناظر با يّيدهاى نوتركيب در لاين هاى غيرتراريخت مشاهده نشد (شكل B (1).

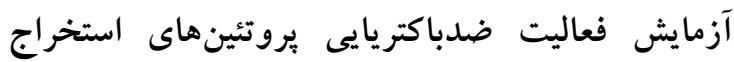
شده از گياهان تراريخت بهروش CFU: يروتئينهاى نوتركيب استخراج شده از كياهان تراريخت در شرايط

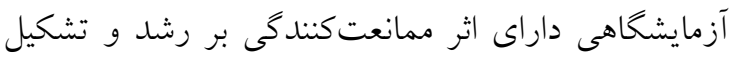
كلونى توسط بيمارگرهاى E.faecium ،.faecalis و E.coli

A)

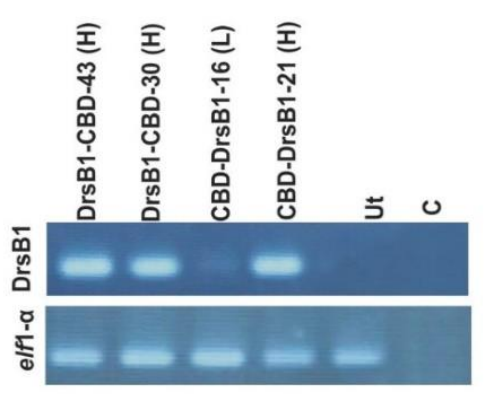

B)

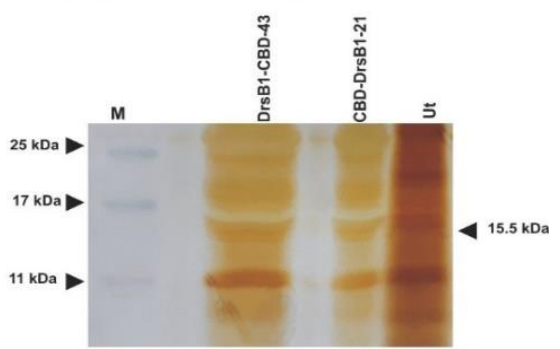

شكل ا

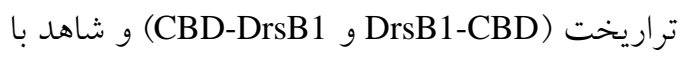

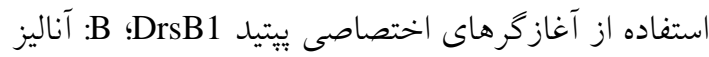

بيان ييتيدهاى نوتركيب تخليص شده و شاهد

غير تراريخت با استفاده از روش SDS-PAGE

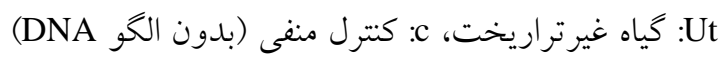

Figure 1. A: Semi-quantitative RT-PCR analysis of transgenic and control plants; B: Sodium dodecyl sulfate-polyacrylamide gel electrophoresis (SDSPAGE (of Ni-IDA purified recombinant peptides in selected transgenic and control plants

Ut: non-transgenic control line and c: negative control 
A)

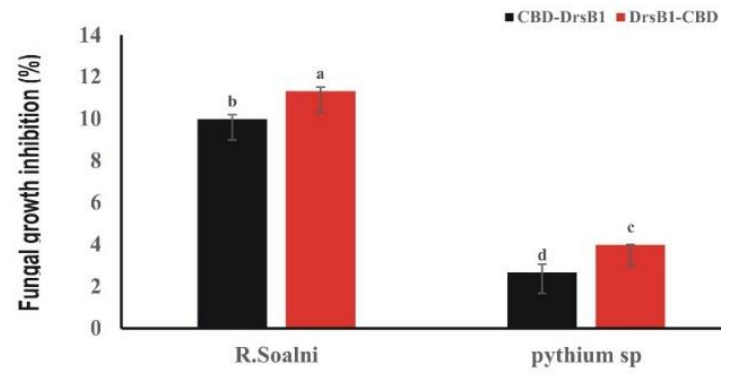

B)

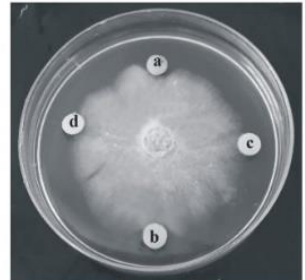

R.solani

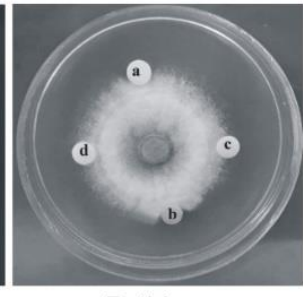

Pythium sp
شكل r A - مقايسه ميانخين اثر ضدقارجى بروتئينهاى

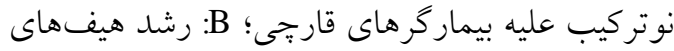

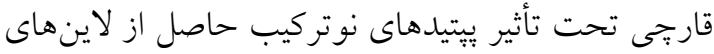
تراريخت

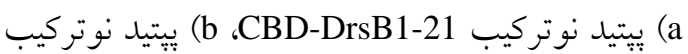

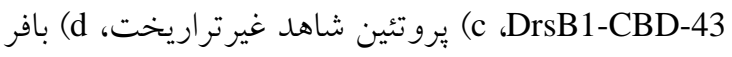
فسفات

Figure 3. A: Means comparison of antifungal activity of recombinant proteins on fungal growth;

B: Growth of fungal hyphae treated with recombinant peptides extracted from selected transgenic lines

a) CBD-DresB1-21, b) DresB1-CBD-43, c) nontransgenic control plant, d) Phosphate buffer

همجنين يِيتيد استخراج شده از لاين DrsB1-CBD-43 بيشترين تأثير بازدارندگى را بر قارجهاى بيمارىزاى مورد بررسى نشان داد. قطرهاله بازدارندكى اين يُهيد نوتركيب روى قارج R.solani در حدود 11 mm بود. همجنين هر دو نوع بروتئين نوتركيب قدرت مهاركنندگى كمترى عليه قارج بيتيوم داشتند. نتايج حاصل از تزريق يِّيدهاى نوتركيب روى ديسك بهخوبى با نتايج حاصل از MIC همخوانى داشت.

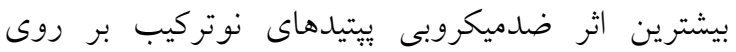
قارجهاى R.solani مشاهده گرديل، بهطورىكه ميزان

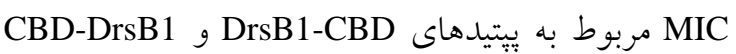
باميزان 10 و ro $\mu \mathrm{g} / \mathrm{ml}$ بود. اين در حالى بود كه

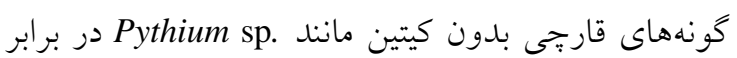

$$
\begin{aligned}
& \text { جدول ا- آناليز ضدميكروبى يِيتيدهاى نوتركيب عليه }
\end{aligned}
$$

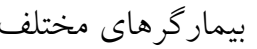

Table 1. Antimicrobial analysis of recombinant peptides against different pathogens

\begin{tabular}{|c|c|c|}
\hline \multirow{2}{*}{ بيماركر } & \multicolumn{2}{|c|}{ درصد كاهش رشد } \\
\hline & CBD-DrsB1 & DrsB1-CBD \\
\hline $\begin{array}{l}\text { Enterococcus } \\
\text { faecium }\end{array}$ & $82.99 \pm 2.1$ & $46.36 \pm 0.87$ \\
\hline $\begin{array}{l}\text { Enterococcus } \\
\quad \text { faecalis }\end{array}$ & $81.5 \pm 1.7$ & $55.76 \pm 2.1$ \\
\hline Escherichia coli & $57.83 \pm 1.87$ & $37.27 \pm 1.3$ \\
\hline 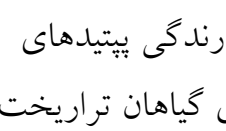 & ، واريانس اثر & نوتركيب جد جد ت \\
\hline
\end{tabular}

Table 2. ANOVA analysis of the inhibitory effects of recombinant peptides on growth of two fungal species

\begin{tabular}{|c|c|c|}
\hline $\begin{array}{c}\text { منبع تغييرات } \\
\text { Source of variation }\end{array}$ & $\begin{array}{c}\text { آزادى درجه } \\
\text { df }\end{array}$ & $\begin{array}{l}\text { ميانخين مربعات } \\
\text { Mean squares }\end{array}$ \\
\hline $\begin{array}{l}\text { قارجها } \\
\text { Fungi }\end{array}$ & 1 & $165.021^{* * *}$ \\
\hline $\begin{array}{c}\text { يُّتيدها } \\
\text { Peptides }\end{array}$ & 1 & $4.68^{* *}$ \\
\hline 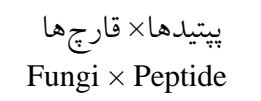 & 1 & $0.021^{\mathrm{ns}}$ \\
\hline $\begin{array}{l}\text { U } \\
\text { Error }\end{array}$ & 8 & 0.125 \\
\hline
\end{tabular}

ضريب تغييرات (.)

Coefficient of variation $(\%)$

و و "*** : بهترتيب غير معنى دار و معنى دار در سطح احتمال ا درصد

${ }^{\mathrm{ns}}$ and **: No significant and significant at $1 \%$ probability levels, respectively

نتايج مقايسه ميانگين اثر متقابل دو جانبه با استفاده از

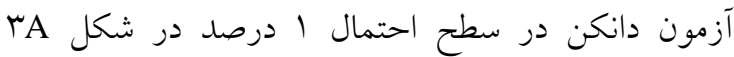
نشان داده شده است. همانطورىكه ملاحظه مى شود هر دو ييتيد نوتركيب از رشد قارجهاى بيمارىزا بهخوبى جلوكيرى نمودند (شكل HA)، اين در حالى بود كه

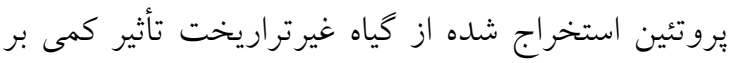
رشد ميسليومى قارجهاى مورد مطالعه داشت (شكل TB). 
نتايج حاصل از مقايسه بين ثروتئين حهاى نوتركيب در

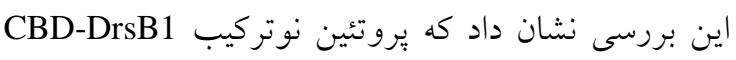

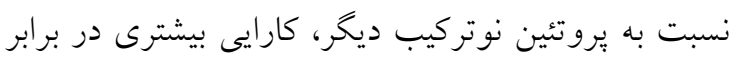

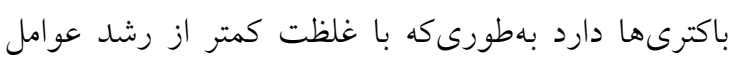
بيمارىزا بهخوبى جلوكيرى مى كند. بهعلاوه، نتايج اين

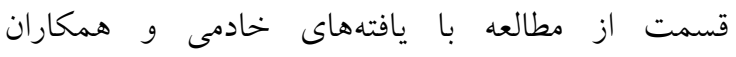
در رابطه با اثرات متفاوت (Khademi et al., 2019a) فعاليت ضدباكتريايى دو يِيتيد نوتركيب مورد نظر مطابقت

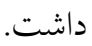

بررسى مطالعات انجام شده بر روى يتيدهاى

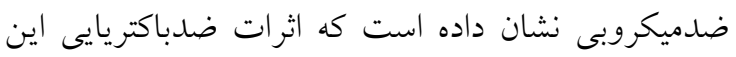
يبتيدها عليه باكترى بيمارىزا بسيار مهم مورد توجه است. براى مثال، بررسى اثر يّيتيد ضدميكروبى Buwchitin نيز عليه باكترىهاى Enterococcus و S.aureus E.coli اثبات شده است (Oyama et al., 2017). در مطالعه حاضر، كارايى و فعاليت يتيدهاى طراحى شده بهصورت In silico

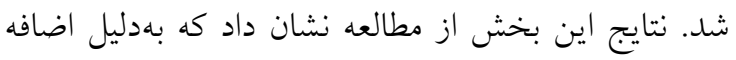

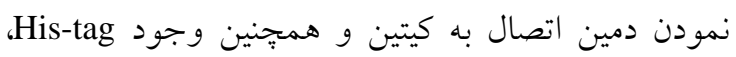

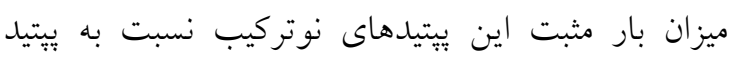

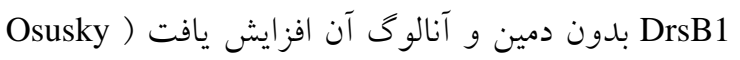

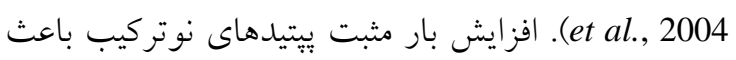

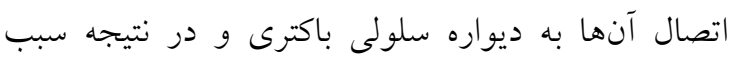

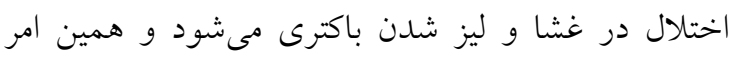

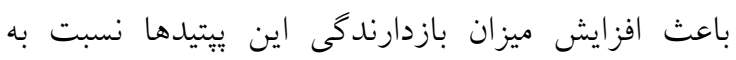

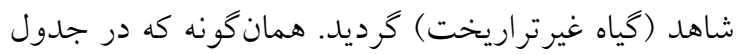
1 مشاهده مىشود، ميزان حساسيت باكترىها نسبت به فه يّيتيد با هم متفاوت بود. بهنظر مىرسد اين مسئله به نحوه مئه

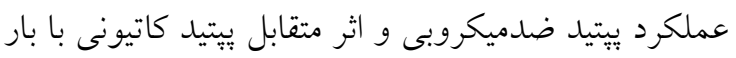
منفى گروههاى فسفولييدها و اسيد لييوتيكوئيك غشاهاى ميكروبى باكترى برمى گردد ) Phoenix et al., 2015; Sohlenkamp and Geiger, 2016; Teixeira et al., 2012). همجنين اضافه كردن دمين اتصال به كيتين از زن نيز بهدليل مشابه بودن ساختار بين كيتين و

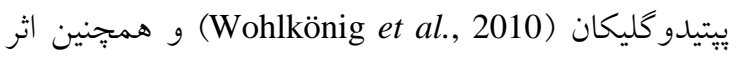

اين يبتيدهاى نوتركيب مقاومتر و داراى حداقل غلظت

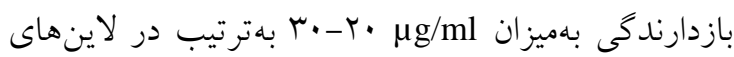
CBD-DrsB1 و بود. DrsB1-CBD در طى جند دهل كذشته، از رويكردهاى مختلفى در

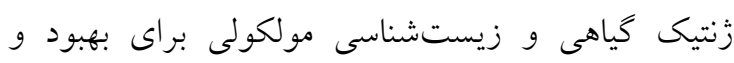

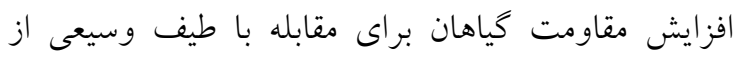

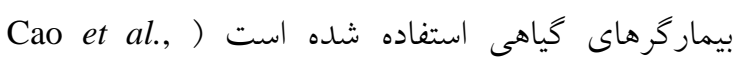
1998). بررسى مطالعات كذشته نشاندهنده فعاليت ضدميكروبى يبتيدهاى نوتركيب DrsB1 در كياه توتون عليه طيف وسيعى از باكترىها و قارجهاى بيمارىزا كياهى بود (Osusky et al., 2004). در همين باهين راستا، بمنظور افزايش تعداد و تراكم ييتيد DrsB1 روى غشاى

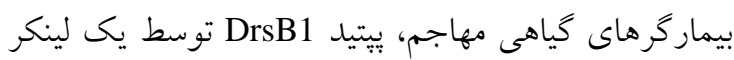

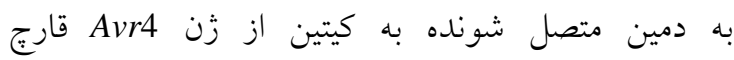
كلادوسيوريوم فلاوم متصل شد تا يروتئين نوتركيب

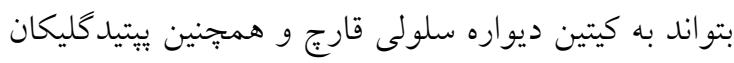

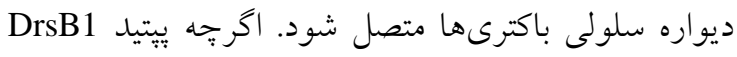

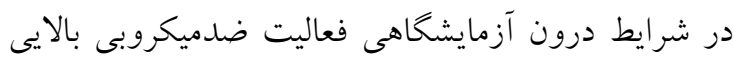

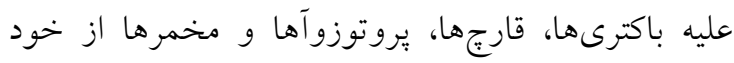

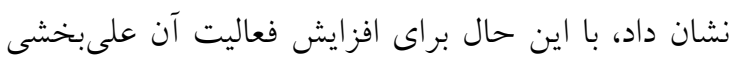

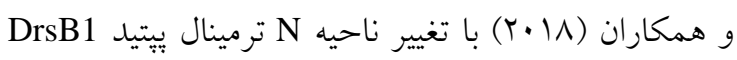

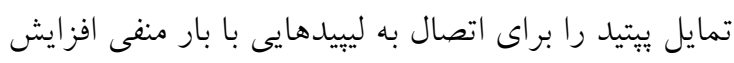

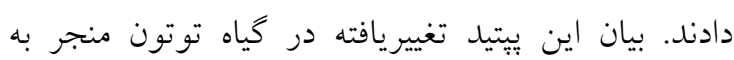

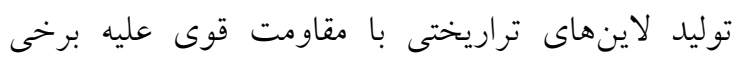
بيماركرها كياهى شد (Alibakhshi et al., 2018).

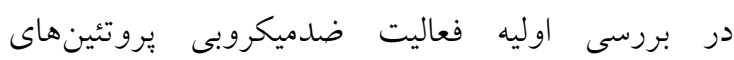

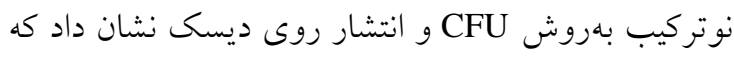
يروتئين هاى نوتركيب داراى فعاليت ضدميكروبى معنى دار

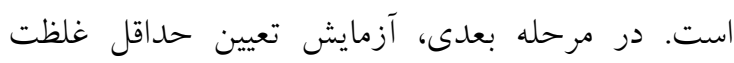

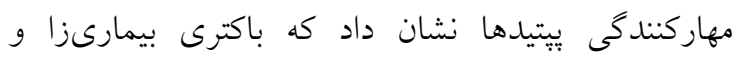
قارجهاى مهم گَاهى بهميزان بالايى در مقابل بروتئينهاى

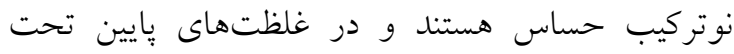

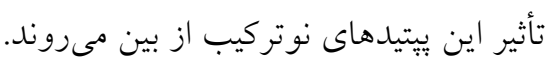


بهمراتب كمتر است (Yan et al., 2008). نتايج حاصل از اين مطالعه نشان داد كه يكى از راهكارهاى مهم در كنترل بيماركرهاى گياهى، هدف قرار دادن كيتين در ساختار

$$
\text { اصلى ديواره سلولى قارجها مىباشد. }
$$

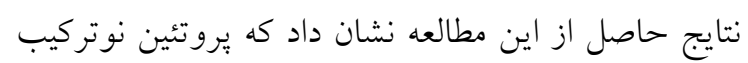
CBD-DrsB1

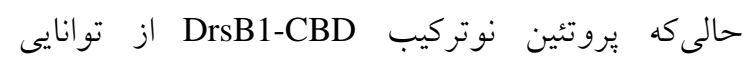

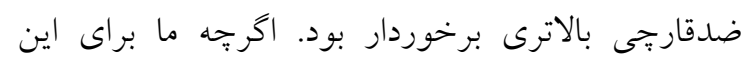

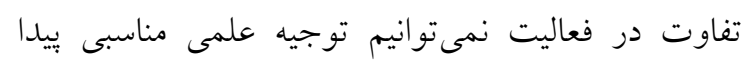
كنيم، اما بهنظر مىرسد كه اين اثرات متفاوت در كياهان

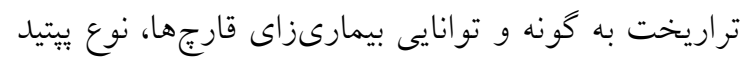

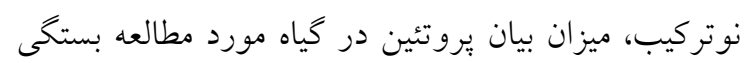

يبتيدهاى ضدميكروبى تركيبات طبيعى و ذاتى سيستم ايمنى در واقع همه موجودات هستند و بيان آنها در ورئيل محصولات تجارى مىتواند استفاده از سموم شيميايى و

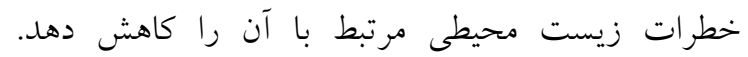

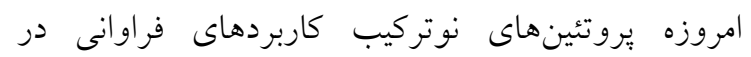

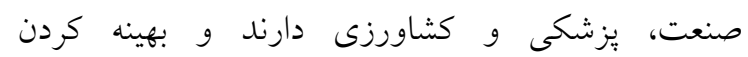
روشهاى توليد اين تركيبات مهم، در توليد محصول

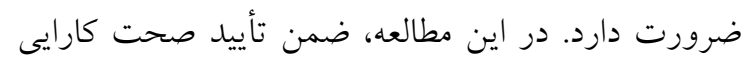

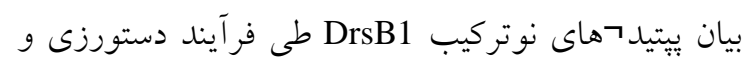

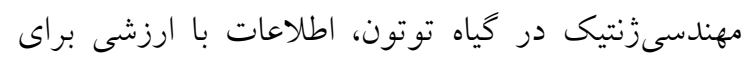

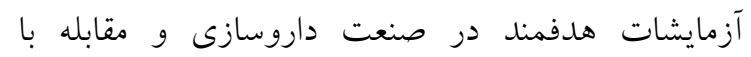

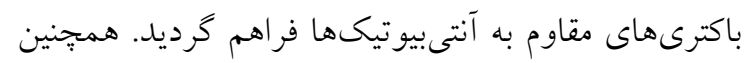

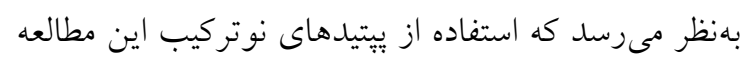

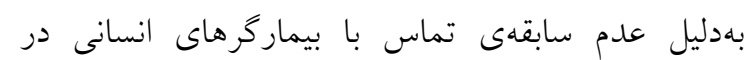

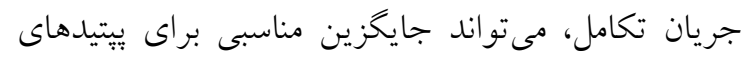
انسانى در امر مقابله با ميكروبهاى بيمارىزا باشد.

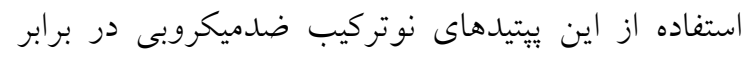

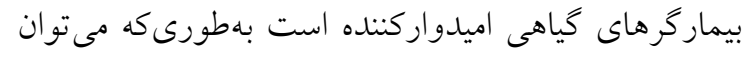
بهطرز جشم گيرى استفاده از سموم شيميايى را در كشاورزى كاهش دهد. اكر جهه هنوز مرحله بعدى تحقيق شامل ارزيابى كلخانهاى و مزرعهاى كياهان تراريخت
متقابل Avr4 با N-استيل كلوكز آمين از يِيتيدو كليكان باعث افزايش فعاليت اين يِيتيدهاى نوتركيب عليه

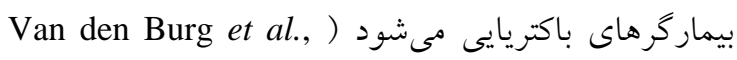

بين قابليت اتصال به كيتين و فعاليت ضدميكروبى ييتيد L.lactis) Cy-AMP C.mutans F.oxysporum (E.cloacae و قارجى (E.carotovora)

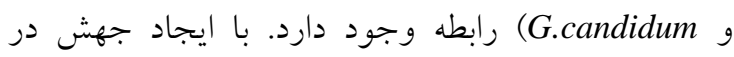
دمين اتصال به كيتين يُيتيد Cy-AMP، اتصال به كيتين و در نتيجه فعاليت ضدقارجى كاهش بيدا كرد، در حالى كه بهاني خاصيت ضدباكتريايى عليه باكترىهاى گرم مثبت و منفى لئى در مقايسه با يِتيد تيب وحشى تغيير نكرد ( Yokoyama (et al., 2009 . تاكنون بهمنظور مبارزه با بيماركرها،

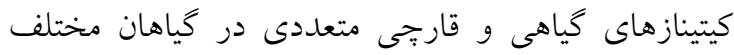
بيان شدهاند و در بيشتر موارد مقاومت بالاترى در

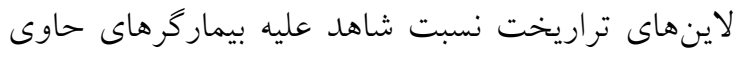

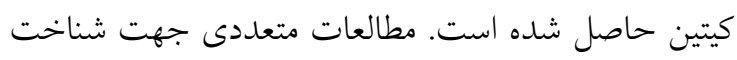

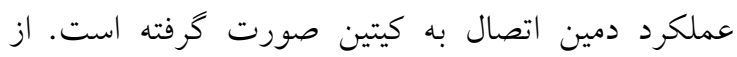
جمله اين مطالعات، مىتوان به مطالعه نقش دمين اتصال

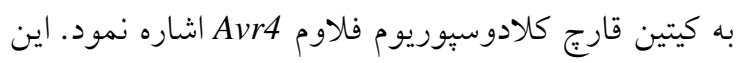
قارج داراى افكتورى به نام Avr4 است كه حاوى دمين اتصال به كيتين مىباشد كه ديواره سلولى قارج رائ رادر برابر كيتينازهاى كياهى محافظت مى كند ( Van den Burg et (al., 2006 بنابراين با توجه به مطالب بالا و افزايش فعاليت

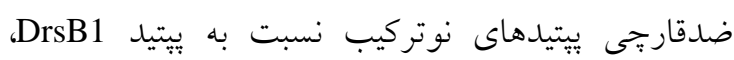

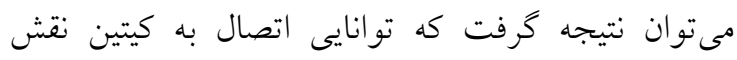
مهمى در فعاليت ضدقارجى ييتيدهاى نوتركيب بازى

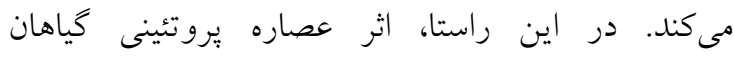

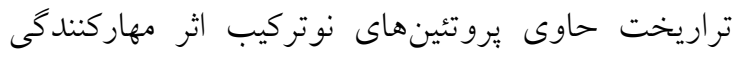

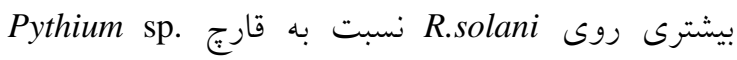
داشتند. اين امر مىتواند به اين خاطر باشد كه ميزان كيتين

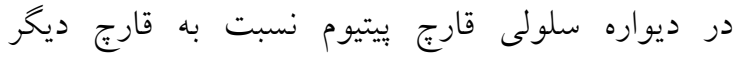




\section{References}

Alibakhshi, A., Nazarian Firouzabadi, F. and Ismaili, A. (2018). Expression and antimicrobial activity analysis of a Dermaseptin B1 antibacterial peptide in tobacco hairy roots. Plant Protection (Scientific Journal of Agriculture), 41(3): 87-96 (In persion).

Barra, D. and Simmaco, M. (1995). Amphibian skin: a promising resource for antimicrobial peptides. Trends in Biotechnology, 13: 205-209.

Bradford, M.M. (1976). A rapid and sensitive method for the quantitation of microgram quantities of protein utilizing the principle of protein-dye binding. Analytical Biochemistry, 72: 248-254.

Cao, H., Li, X. and Dong, X. (1998). Generation of broad-spectrum disease resistance by overexpression of an essential regulatory gene in systemic acquired resistance. Proceedings of the National Academy of Sciences, 95: 6531-6536.

Conlon, J.M., Kolodziejek, J. and Nowotny, N. (2004). Antimicrobial peptides from ranid frogs: taxonomic and phylogenetic markers and a potential source of new therapeutic agents. Biochimica et Biophysica Acta (BBA)-Proteins and Proteomics, 1696: 1-14.

Flavia Cancado Viana, J., Campos Dias, S., Luiz Franco, O. and Lacorte, C. (2013). Heterologous production of peptides in plants: fusion proteins and beyond. Current Protein and Peptide Science, 14: $568-579$.

Fujikawa, T., Sakaguchi, A., Nishizawa, Y., Kouzai, Y., Minami, E., Yano, S., Koga, H., Meshi, T. and Nishimura, M. (2012). Surface $\alpha$-1, 3-glucan facilitates fungal stealth infection by interfering with innate immunity in plants. PLoS Pathogens, 8: e1002882.

Hajiahmadi, Z., Shirzadian-Khorramabad, R., Kazemzad, M. and Sohani, M.M. (2017). Expression of cryIAb Driven by a Wound Inducible Promoter (MPI) in Tomato to Enhance Resistance to Tuta absoluta. Plant Genetic Researches, 4(2): 1-16 (In Persian).

Holaskova, E., Galuszka, P., Frebort, I. and Oz, M.T. (2015). Antimicrobial peptide production and plant-based expression systems for medical and agricultural biotechnology. Biotechnology Advances, 33: 1005-1023.

Hunter, P.A., Darby, G., Russell, N.J. and Russell, A.D. (1995). Fifty Years of Antimicrobials: Past Perspectives and Future trends. The Press Syndicate of the University Cambridge; New York, USA.

Khademi, M., Nazarian-Firouzabadi, F. and Ismaili, A. (2019a). Cloning and expression of two new recombinant antimicrobial dermaseptin b1 peptides in tobacco to control the growth of human bacterial pathogens. Journal Mazandaran University, 29(176): 47-60 (In persion).

Khademi, M., Nazarian-Firouzabadi, F., Ismaili, A. and shirzadian-khorramabad, R. (2019b). Targeting microbial pathogens by expression of new recombinant dermaseptin peptides in tobacco Microbiologyopen online, Special issue: 1-11.

Latgé, J.P. and Beauvais, A. (2014). Functional duality of the cell wall. Current Opinion in Microbiology, 20: 111-117.

Latgé, J.P. (2010). Tasting the fungal cell wall. Cellular Microbiology, 12: 863-872.

Li, Z., Zhou, M., Zhang, Z., Ren, L., Du, L., Zhang, B., Xu, H. and Xin, Z. (2011). Expression of a radish defensin in transgenic wheat confers increased resistance to Fusarium graminearum and Rhizoctonia cerealis. Functional \& Integrative Genomics, 11: 63-70.

Osusky, M., Osuska, L., Hancock, R.E., Kay, W.W. and Misra, S. (2004). Transgenic potatoes expressing a novel cationic peptide are resistant to late blight and pink rot. Transgenic Research, 13: $181-190$.

Oyama, L.B., Crochet, J.A., Edwards, J.E., Girdwood, S.E., Cookson, A.R., Fernandez-Fuentes, N., Hilpert, K., Golyshin, P.N., Golyshina, O.V. and Privé, F. (2017). Buwchitin: A Ruminal Peptide with antimicrobial potential against Enterococcus faecalis. Frontiers in Chemistry, 5: 51.

Phoenix, D.A., Harris, F., Mura, M. and Dennison, S.R. (2015). The increasing role of phosphatidylethanolamine as a lipid receptor in the action of host defence peptides. Progress in Lipid Research, 59: 26-37. 


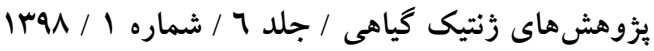

Nazarian-Firouzabadi, F. (2014). Manipulation of starch biosynthasis and in planta biopolymer production. Plant Genetic Researches, 4(2): 1-14 (In Persian).

Sohlenkamp, C. and Geiger, O. (2016). Bacterial membrane lipids: diversity in structuresand pathways. FEMS Microbiology Letters, 40: 133-159.

Stone, S.L. and Gifford, D.J. (1997). Structural and biochemical changes in loblolly pine (Pinus taeda L.) seeds during germination and early-seedling growth. I. Storage protein reserves. International Journal of Plant Sciences, 158: 727-737.

Teixeira, V., Feio, M.J. and Bastos, M. (2012). Role of lipids in the interaction of antimicro-bial peptides with membranes. Progress in Lipid Research, 51: 149-177.

Thomma, B.P., Nürnberger, T. and Joosten, M.H. (2011). Of PAMPs and effectors: the blurred PTI-ETI dichotomy. The Plant Cell Online, 23: 4-15.

Van den Burg, H.A., Harrison, S.J., Joosten, M.H., Vervoort, J. and de Wit, P.J. (2006). Cladosporium fulvum Avr4 protects fungal cell walls against hydrolysis by plant chitinases accumulating during infection. Molecular Plant-Microbe Interactions, 19: 1420-1430.

Van den Burg, H.A., Spronk, C.A., Boeren, S., Kennedy, M.A., Vissers, J.P., Vuister, G.W., de Wit, P.J. and Vervoort, J. (2004). Binding of the Avr4 elicitor of Cladosporium fulvum to chitotriose units is facilitated by positive allosteric protein-protein interactions. Journal of Biological Chemistry, 249: 16786-16796.

Vidaver, A.K. (2002). Uses of antimicrobials in plant agriculture. Clinical Infectious Diseases, 34: S107-S110.

Vlietinck, A. (1991). Screening methods for antibacterial and antiviral agents from higher plants. Methods in Plant Biochemistry, 6: 47-69.

Wohlkönig, A., Huet, J., Looze, Y. and Wintjens, R. (2010). Structural relationships in the lysozyme Superfamily: significant evidence for glycoside hydrolase signature motifs. PLoS One, 5: e15388.

Yan, R., Hou, J., Ding, D., Guan, W., Wang, C., Wu, Z. and Li, M. (2008). In vitro antifungal activity and mechanism of action of chitinase against four plant pathogenic fungi. Journal of Basic Microbiology, 48: 293-301.

Yokoyama, S., Iida, Y., Kawasaki, Y., Minami, Y., Watanabe, K. and Yagi, F. (2009). The chitinbinding capability of Cy-AMP1 from cycad is essential to antifungal activity. Journal of Peptide Science, 15: 492-497.

Zasloff, M. (2002). Antimicrobial peptides of multicellular organisms. Nature, 415: 389-395.

Zasloff, M. (2006). Defending the epithelium. Nature Medicine, 12: 607-608. 


\title{
Expression and Antimicrobial Activity Analysis of Dermaseptin B1 Recombinant Peptides in Tobacco Transgenic Plants
}

\section{Mitra Khademi ${ }^{1}$ and Farhad Nazarian-Firouzabadi ${ }^{2}$,*}

1- Ph.D., Department of Agronomy and Plant Breeding, Faculty of Agriculture, Lorestan University, Khorramabad, Iran

2- Professor, Department of Agronomy and Plant Breeding, Faculty of Agriculture, Lorestan University, Khorramabad, Iran

(Received: April 15, 2019 - Accepted: July 21, 2019)

\begin{abstract}
Recently, new molecular breeding and genetic engineering approaches have emerged to overcome the limitations of conventional breeding methods in generating disease-resistance transgenic plants. The use of antimicrobial peptides (AMPs) to produce transgenic plants resistant to a wide range of plant pathogens has achieved great success. Among huge number of AMPs, Dermaseptin B1 (DrsB1), an antimicrobial cationic 31 amino acids peptide, exhibits significant antimicrobial activities towards a wide range of pathogens. In order to increase the antimicrobial efficacy of DrsB1, the DrsB1 encoding DNA sequence was either fused to the $\mathrm{N}$ - or $\mathrm{C}$-terminus of the sequence encoding chitin-binding domain (CBD) of Avr4 gene from Cladosporium fulvum and constructs (CBD-DrsB1 and DrsB1CBD) were used for tobacco leaf disk Agrobacterium-mediated transformation. Polymerase chain reaction (PCR), semi-quantitative RT-PCR and SDS-PAGE analysis indicated the integration of transgenes in tobacco genome and expression of the recombinant genes in transgenic plants, respectively. The antimicrobial activity of extracted recombinant peptides were assessed against a number of plant and human pathogens. Both recombinant peptides had statistically significant $(\mathrm{P}<0.01)$ inhibitory effects on the growth and development of fungi pathogens. Also, CFU test result showed that extracted recombinant peptides from transgenic plants, had a relatively high inhibitory effect on plant pathogens. The CBD-DrsB1 recombinant peptide demonstrated a higher antibacterial activity, whereas the DrsB1-CBD recombinant peptide performed a greater antifungal activity. In addition, the expression of DrsB1-CBD recombinant peptide significantly inhibited R.solani fungal infection in comparison with Pythium sp. interestingly, fungi with a higher amount of cell wall chitin were more vulnerable to recombinant peptides, suggesting recombinant peptides present a higher affinity for cell wall chitin. Owing to the high antimicrobial activity and novelty of recombinant peptides, this strategy for the first time, could be used to generate transgenic crop plants resistant to devastating plant pathogens.
\end{abstract}

Keywords: Gene expression, Pathogens, Antimicrobial peptide, Chitin-binding domain, Genetic engineering

\footnotetext{
*Corresponding Author, E-mail: nazarian.f@lu.ac.ir
} 